\title{
Supranational Regulation
}

\section{Television and the European Union}

\section{- Mark Wheeler}

\section{A B S T R A C T}

- This article analyses, assesses and explains the imperatives which have affected the European Union's (EU) audiovisual policy instruments, with particular emphasis on the Television without Frontiers (TWF) Directive, cross-media ownership regulations and the regulatory frameworks concerning converging communication services. It considers the factors which have led to competition policy becoming more important in the era of convergence and globalization. Finally, it considers whether these regulatory responses and policy interpretations illustrate the extent to which the Commission has been able (or not) to balance the increasingly conflicting imperatives of economic competitiveness with the core values of cultural identity.

Key Words competition, convergence, culture, European Union, regulation

\section{Introduction}

The European Union's (EU) regulation of European television and audiovisual services was established within a number of vague provisions in Article 151 of the basic European Treaty (European Union, 1997a). Recently, the European Commission's (EC) competence for audiovisual services has incrementally grown as technological reforms enabled operators to develop at a pan-European level. In developing a regulatory approach to television and audiovisual services, the EU's response

Mark Wheeler is senior lecturer in the Governance and International Relations Section, London Metropolitan University (City Campus), Calcutta House, Old Castle Street, London E1 7NT, UK [email: m.wheeler@londonmet.ac.uk].

European Journal of Communication Copyright (C) 2004 SAGE Publications (London, Thousand Oaks, CA and New Delhi) www.sagepublications.com, Vol 19(3): 349-370. [10.1177/0267323104045263] 
signalled a conflict between the economic priorities of industrial competitiveness on the one hand and the desire to maintain the principles of European cultural identity on the other:

Broadcasting and the audiovisual has therefore been a notable site where one of the 'grand narratives' of the Community has been played out, the battle between the interventionists and free marketers, between 'dirigistes' and 'ultra liberals'. (Collins, 1994: 23)

Technological reform, cross-sectoral convergence, economic opportunity and the globalization of communications services have brought new entrants, strategic alliances, acquisitions and corporate media marriages and mergers into the European television marketplace. Thus, within an expanding market, one of the constant themes underpinning the EU's policy responses has been liberalization of the rules governing Europe's television industries. This, the Commission felt, would improve European media companies' competitiveness against the challenges of foreign broadcasters, most especially from the US, and allow the companies to establish a worldwide presence.

Simultaneously, the EU's audiovisual policies sought to preserve the social, cultural and political priorities which have been associated with the provision of pluralism through diverse and 'high-quality' television services in democratic societies. While the Commission has been concerned with content regulation, it has been legally required to utilize economic or structural forms of regulation to intervene over cultural matters. Consequently, the EU has been concerned with the issues surrounding media concentration to ensure open and fair competition. Further, the Commission has developed a limited number of measures maintaining the public service tradition with regard to the matters of state aids and subsidies. Yet as public service broadcasters (PSBs) have been understood as constraining the internal market, a number of EU institutions, most especially the Competition and Information Society Directorates have become hostile towards them.

This article comments on the EC's audiovisual policy instruments, with special emphasis on the Television without Frontiers (TWF) Directive, cross-media ownership regulations and the regulatory frameworks concerning converging communication services. It discusses how the role of competition policy has become more important in the era of convergence. Finally, it considers whether these regulatory responses and policy interpretations illustrate the extent to which the EC has been able (or not) to balance the increasingly conflicting imperatives of economic competitiveness with the core values of cultural identity. 
The EU's competing motives: market efficiency alongside core values

The EU has always been concerned about the relative weakness of European television industries within the global marketplace as European television companies are too small to compete internationally. In particular, the European television industry has become characterized by the growing disjunction between a small number of well-capitalized broadcasters who control electronic delivery systems against a larger number of undercapitalized organisations, who will become smaller and more fragmented (Davis, 1998: 80).

These difficulties have meant that European television markets stood at a considerable disadvantage against US producers, who were more efficient in the distribution of their product to large international audiences as they could pursue greater economies of scale and the substantive price advantages because of the size of their own domestic market. This led to an imbalance between the demands for programmes (which reflected the growth in channels and airtime to fill) against the limitations governing European production capacity. In turn, there has been a reliance on US imports for fictional programming such as dramas and situation comedies due to their cheapness in cost over domestic production.

Thus, with the expansion of television and audiovisual services, which was associated with the diversification of revenue streams available to media companies (resulting in an exponential rise in the number of television hours to be filled), the EU believed that its role should be to facilitate the unification of the fragmented national European television industries. This would create a more sustainable European television economy which could develop the programming infrastructure to compete with the influx of US imports. In particular, Commission officials suggested that through the removal of national forms of protectionism the European companies might compete on a global basis and felt that once market barriers had been lowered the:

European countries would satisfy their demand for programming from increases in European production . . . rather than gravely increased dependence on US imports. (Humphreys, 1996: 261)

To foment the rapid growth of the European television market, the EU's (de)regulatory principles of liberalization and harmonization have underpinned its approach to the audiovisual sector throughout a series of directives such as TWF and policy approaches concerning media concentration and regulation of competition. These provisions, for a 
European-wide liberalization of broadcasting markets, were in accord with the EU's overarching goal of single market integration which had been enshrined by the 1992 Maastricht Treaty (European Union, 1992a).

Simultaneously, within this era of single market integration and commercial opportunity, the Commission sought to preserve and protect what it perceived to be the traditional core values and strengths of the European broadcasting economies. These included:

- Pluralism, the most fundamental public objective in the media sector;

- Cultural diversity, especially regarding the preservation of national identities; and

- The enhancement of citizen's choice, in which consumers will be able to enjoy a wide degree of access to the new opportunities provided by market innovation (Ungerer, 2002: 4).

The Treaty on the European Union, which came into force on 1 November 1993, makes a specific reference to the audiovisual sector. It specifies that, under its provisions, the Community will be required to take all cultural aspects into account in its actions concerning audiovisual services (European Union, 1992a). In 1999, the Prodi Commission defined its position concerning the regulation of content in a Communication titled 'Principles and Guidelines for the Community's Audiovisual Policy in the Digital Age', which was endorsed by the Council and the European Parliament (European Union, 1999d). The Communication reaffirmed that regulation within the audiovisual sector must safeguard such public interest objectives as: pluralism; cultural and linguistic diversity; copyright protection; the right of reply; and the protection of minors. Thus, the Commission commented that the extent of any subsequent regulation should be determined by the failure of the market to realize these objectives. Moreover, it was contended that regulation must remain proportionate (e.g. the minimum necessary to achieve the Commission's goals) (Reding, 2000).

The EU has also developed a series of support measures which were designed to enable the audiovisual sector to compete with the US. In particular, the EU established the MEDIA I and MEDIA II programmes which allocated $\boldsymbol{€} 200$ million for a five-year period between 1991 and 1996 and $\boldsymbol{\epsilon} 310$ million for a four-year period between 1996 and 2000 (focusing on training, development and distribution) respectively. Since January 2001, the $€ 400$ million MEDIA Plus programme has been 
enforced to strengthen the European audiovisual industry through the continued support and co-financing of training, development, distribution and the promotion of programmes. However, as some commentators have noted, these subsidies were only a fraction of the total monies which existed in the sector (Levy, 1999: 49).

Further, the divisions between liberalizers and dirigistes were complicated by the expansion of services that emerged as a consequence of the digitalization and convergence of communication services (television, telecommunications and information). The increase within digital television platforms has meant that EU regulators have become concerned with the conditional access systems which allow consumer access to services through set-top boxes and the need to ensure that there should be no bottlenecks over content in the supply of communication services to users.

\section{Public service broadcasters}

The tensions between the liberalizers and interventionists have been most problematic with regard to PSBs. DGX (now Education and Culture) has been, with the European Parliament, largely in favour in pluralism and to a lesser degree supportive of PSBs. Elsewhere, DGIV (now Competition) was 'implacable [in its] pursuit of public service broadcasters' (Collins, 1994: 155-6; 1999: 161) and from the late 1980s to early 1990s, the Directorate addressed complaints from commercial organizations about PSBs. For DGXIII (now Information Society), who favoured liberalizing measures which would expand the television marketplace by removing the 'constraints' on growth for media companies, PSBs were dominant players who undermined an unfettered marketplace (Radaelli, 1999: 129; Humphreys, 1996: 260).

In attempting to rectify these difficulties, the EU established the 1997 Protocol of Amsterdam, which was annexed to the Treaty of Amsterdam, to consider the role of public subsidies in the competitive balance between public and commercial broadcasters (European Union, 1997b). In particular, commercial channels in Spain, France, Germany, Italy and Denmark had complained to the EC about the dual forms of funding (licence fees and advertising) which supported their national PSBs and, the commercial forces claimed, gave the PSBs an unfair advantage. The protocol was designed to rectify any unfairness between competitive gain and the maintenance of diverse and pluralistic services through the public service tradition. It commented that public subsidies could only be granted to PSBs when: 
... such funding does not affect trading conditions and competition in the Community to an extent which would be contrary to the common interest, while the realisation of the remit of that public service shall be taken into account. (Papathanassopoulos, 2002: 72)

Thus, the protocol made clear that the EU would continue to allow PSBs access to public funds only when they did not distort the commercial market (European Union, 1997b). Simultaneously, the protocol created confusion concerning how competition policy could be employed to investigate complaints about PSBs (Levy, 1999: 96).

Subsequently, the EU supported the 1998 High Level Group on Audiovisual Policy, whose report The Digital Age: European Audiovisual Policy recommended that there should be a maintenance of the distinctive dual systems of public and private broadcasters within the member states (European Union, 1998). It commented that it should be up to the member states to determine the balance of power between the public and commercial sectors in accord with the market forces underpinning their national television marketplaces. Yet, in the same year, the Competition Directorate placed stricter limits on PSBs with regard to state aid rulings. Most especially, public aid would be prohibited when subsidies, alongside advertising revenues, exceeded the costs of meeting public service obligations (Papathanassopoulos, 2002: 72). Despite the Directorate's attempts to introduce draft guidelines in the application of state aids, the majority view in the Commission remained that complaints against PSBs should be considered on a case-by-case basis. However, in spite of the compromises that have marked the EC's response to PSBs:

... the internal market is hostile to public service broadcasting . . . [as when]... seen from the vantage point of the neo-classical economic theory underpinning the EEC Treaty, public service broadcasting is aberrant and offensive. (Collins, 1999: 162) < Hyperlink > Such hostility to PSBs was especially evident in the Commission's development of directives and measures which sought to treat broadcasting as being no different from any other service or commodity.

\section{The Television Without Frontiers (TWF) Directive}

The 1989 TWF Directive (89/552/EEC) remains the liberalizing centrepiece of the EU's legal framework for the audiovisual sector (European Union, 1989). TWF was subsequently amended in 1997 by the European Parliament and the Council in Directive 97/36/EC to provide member states with national measures to protect public access to free-to-air television coverage of major events which have societal worth 
including the Olympics and the World Cup (European Union, 1997d). In 2000, the Education and Cultural Directorate announced that, in the light of the potential change in the European television economy which had accompanied the introduction of digital based services, there would be a further review of the Directive, from which deliberations would be realized during 2003.

Most crucially, TWF provided rules which were aimed at encouraging growth within the European television marketplace and stimulating audiovisual production in countries with a small production capacity. Article 2, which stands at the heart of the Directive, effectively abolished the EU member states' sovereignty over their national systems, thereby facilitating the free movement of television broadcasting services across frontiers within the Union. To this end, the EU employed the Maastricht Treaty's concept of mutual recognition, which meant that, as long as minimal regulatory rulings were met by the provisions of the originating member state, the legal justifications for another member state to impede the reception or retransmission of broadcasts were removed (Collins, 1994: 59-60).

Other liberalizing recommendations were also designed to harmonize the development of a single European market in broadcasting and related activities, such as television advertising, programme sponsorship and the independent production of television programmes. The Directive allowed for the unrestricted flow of programmes carrying advertising across borders and settled on a maximum 15 percent advertising limit of daily airtime, with a maximum of 20 percent per hour during peak schedules. With regard to sponsorship, the Directive simply commented that programme sponsors should not be able to shape editorial influence over programme content, while banning the sponsorship of news and current affairs programming. The Commission's liberalizers were, however, disappointed by the limited 10 percent transmission time or alternatively budget quotas on broadcasters for European works by independent productions (Harcourt and Radaelli, 1997: 8).

Despite the liberalizing arguments that have underpinned the EC's approach in establishing the Directive, culturalists within the EU were able to include provisions to ensure a more interventionist regulatory response to the European television economies (Radaelli, 1999: 125). Thus, TWF included stronger content regulations to be applied within member states' national broadcasting systems (Article 3). Articles 4 and 6 established rules governing the definitions, amounts and nature of European content in television broadcasts. Within Article 6, the Directive provided a definition for 'European works', suggesting that 
these were productions that originated from member states and third party states (non-EU European countries) as defined by the Council of Europe's European Convention on Transfrontier Television.

In Article 4, member states were required to ensure that broadcasters should, where practicable and through appropriate means, reserve a majority proportion of their transmission time for European works (excluding news, advertising and sports events). In effect, it established a clear quota of European works across EU member states.

Other interventionist measures included the establishment of a public right to reply and the protection of minors from undesirable programming. Moreover, the 1997 Amendment, added several public interest requirements including access rights to 'events of major importance for society' and provided member states with the national measures to define a list of designated televised events for that purpose. Thus, TWF was not only important in

. . . its assertion of the economic imperatives of a single broadcasting market but in the Commission's assertion that cultural matters were indeed part of its jurisdiction, albeit via an economic back door . . . [therefore] cultural concerns.. . [have come] to have an important place in Community broadcasting policy (in spite of the absence of the Treaty of Rome as a basis for Community cultural policy). (Collins, 1994: 3)

Overall, however, the TWF Directive was established to stem any inefficiency which resulted from what it perceived as unnecessary forms of national regulation, so that a liberalized single European audiovisual market could flourish. Even Articles 4 and 6 were not fully interventionist, as they defined 'European' as referring to 'any legal or natural person domiciled in any of the member states of the Council of Europe' (Collins, 1994: 70). This was a permissive definition suggesting that US companies which are based in Europe may be understood as being 'European'. Additionally, the articles contained get-out clauses concerning practicability and also stated that their aim for European production 'should be achieved progressively' (Humphreys, 1996: 277).

Further, there were major disagreements on the quota provisions as defined by Article 4, and from 1989 until 1997 the quotas (even among their supporters) were 'valued increasingly in terms of the symbolic rather than real' (Levy, 1999: 48). Only a few EU dirigistes, who called for the quotas to become obligatory rather than being observed through choice, believed that these measures could offset the still limited but growing reliance by European broadcasters on imports. Instead, these measures provided a central plank for those within the Commission who felt that 
the audiovisual sector should not be left to the deliberations of the market. In the event, the 1997 revision of the TWF Directive signalled an end to this debate when the European Parliament decided to vote against the toughening up of the quotas (Levy, 1999: 48).

Thus, in many respects, the Commission may be understood as developing the Directive in 1989, and through its further revision in 1997, from a liberal view which ignored the wider political issues of pluralism and cultural diversity (Radaelli, 1999: 125). TWF was in effect 'a victory for commercial forces and those who favoured anti-protectionist policies' (Negrine and Papathanassopoulos, 1990: 76).

\section{The regulation of media concentration in a converging communications market}

To ensure an open media marketplace in Europe, thereby stemming possible media concentration brought about by the growth of vertically integrated conglomerates, the TWF Directive stated that its aim was to make sure that competition must not, in any shape, be distorted. However, Article 5 (which established the $10 \%$ quota for independent production) was the only explicit measure in TWF which dealt with media concentration and then from an economically liberal viewpoint. Humphreys (1996:.287).

Therefore to rectify this omission, in the early 1990s, the EU declared that it would establish a directive concerning the concentration of media ownership through the harmonization of national rulings. However, as Levy comments:

... there was disagreement between the Community's institutions as to whether the primary purpose of Community action was the safeguarding of pluralism or the competition of a single European audiovisual market. (Levy, 1999: 51)

The lines of demarcation within this dispute were indicated by the differences in approach between the 1992 Green Paper on 'Pluralism and Media Concentration in the Internal Market' (COM (92) 480 final, European Union 1992b) and 'Europe and the Global Information Society' written by the Bangemann High-Level Group in 1994 (European Union, 1995).

The former set out to assess the need for Community level action concerning media ownership with regard to the disparities that existed among member states. It outlined a lengthy process in which there would be a facilitation of a network of like-minded operators who would be consulted with regard to questions on pluralism and media ownership 
(Iosifides, 1997: 91-104). Conversely, the 1994 paper described a situation across Europe, in which national ownership regulations had impeded television and telecommunications companies from taking new opportunities in the internal market, with regard to information services (European Union, 1995). In turn, it speculated that such regulatory restrictions would undermine the competitive advantage of European television organizations against non-European competitors (Iosifidis, 1997: 94).

Commissioner Mario Monti tried to reconcile these goals when he presented a draft directive in 1996, whose measures included: a 30 percent upper limit on 'monomedia' ownership for radio and television broadcasters in their own territories and a 'multimedia threshold' of 10 percent for ownership of combined media (television, radio and newspapers) (Levy, 1999: 50-2). These proposals floundered as the member states disputed the appropriate level of diversity within ownership for the different sized markets (local, regional or national). While the Commission favoured an overall measure of a 30 percent market share within a specific region for a television or radio station, some Community members (notably Germany and the UK) argued that market share should be measured in accordance with the media companies' national marketplaces, irrespective of where the service was transmitted. Following on from this, a more flexible draft proposed a 30 percent share which could be varied in respect to each set of national circumstances.

However, the Commission was unable to secure a compromise between the European Parliament and the member states over the degree of flexibility governing ownership thresholds at local, regional or national levels (Papathanassopoulos, 2002: 112-13). In the event, the draft directive was abandoned in 1998, when the EU decided to establish a set of rulings on ownership, plurality and diversity through a number of policy documents and research reports. Invariably, the recommendations and rulings within these policy documents were limited. This was because the basic Treaty provisions, in accordance with the principles of subsidiarity, stated that ownership rules should fall within the regulatory supervision of the member states. Moreover, due to the political sensitivity of any rulings concerning media ownership, the EU found it difficult to establish a consensus among member states (in contrast to the general support of the liberalizing and harmonizing measures within TWF) favouring Community-level intervention regarding media ownership. This was also reflected in the lukewarm response from the media industries themselves when presented with the possibility of a set of harmonized European-wide rulings governing cross-media ownership. 
Therefore, the political controversy that arose concerning these rulings showed the fundamental dichotomy in the EU's approach between the desire for plurality in media provision and the need to establish a competitive European television sector. These differences were also played out within the Commission itself, notably between the main EU Directorates. DGX (Education and Culture) continued to seek to preserve the concepts of plurality, while DGXIII (Information Society and at the time headed by Commissioner Martin Bangemann) pursued policies which were designed to expand information services through market liberalization, on account of the new market conditions which had emerged under convergence.

\section{The 1997 EU Green Paper on the regulation of convergence}

In the midst of these differences concerning the EU's response to media concentration, the situation was complicated as European policy-makers anticipated that there would be an explosion of new communication channels accompanying the convergence of broadcasting, telecommunication and information services. For the EC's market-liberals, the potential opportunities for new entrants, which had been opened up by the trends towards consolidation and diversification that accompanied convergence, needed to be encouraged. Consequently, views differed about whether digitalization and the proliferation of new channels and services would make the need for specific rulings concerning concentration relevant or not.

The 1997 Green Paper on the 'Convergence of the Telecommunications, Media and Information Technology, and the Implications for Regulations, towards an Information Society Approach' (COM (97) 623) commented that new opportunities for communication actors should be encouraged through a review of the current rules (European Union, 1997c). The paper also felt that, as consumers would enjoy increased choice across a variety of digital channels, PSBs might decline in terms of visibility. Thus, the regulatory frameworks should enable public broadcasters access to the valuable new revenues alongside the current forms of funding, as long as the publicly drawn incomes did not cross-subsidize such activities. Most especially, it predicted that convergence would act as a panacea to Europe's depressed labour markets and a powerful motor for economic growth (European Union, 1997c: 4).

The Green Paper argued that regulatory barriers could hinder the development of a sustained communications economy within Europe and that traditional structures were insufficiently adaptable to the changing 
needs of the marketplace (European Union, 1999a). Consequently, it questioned the rationales underpinning the existing rules suggesting that they were bound by the previous norms of public service, sectoral differentiation, geographic boundaries and analogue transmission systems alongside general assumptions about 'monomedia' players. It was felt that such forms of regulatory control might promote uncertainty, thereby restricting the opportunities for investment in the audiovisual sector and serving to undermine the prospects of developing the information society'.

The Green Paper argued, with regard to media concentration, that vertical merger activity would be an inevitable consequence of convergence. This was due to the fact that only a few of the major media players had the sufficient resources and skills to 'straddle the whole value chain within the converged environment, so that the emergence of major players will inevitably rely on partnering to varying degrees' (European Union, 1997c: 7).

\section{The European Parliament's calls for a resolution on media concentration}

After the Commission's failure to establish the Directive on Media Concentration and the Green Paper's endorsement of media consolidation in the converging communications environment, the European Parliament in its 1999 response to the Convergence Green Paper called for the Commission to submit a further proposal for such a directive (European Union, 1999a). Yet, in the following three years the EC failed to address the issue. Therefore, on 20 November 2002, the Parliament called on the Commission to consider media concentration by launching a comprehensive consultation to assess how new technologies and corporate mergers, alliances and joint ventures had impacted on the European audiovisual market. It argued that this should occur to safeguard media pluralism and offset the growing disparity in national anti-concentration rulings. The European Parliament stated that Commission should draft an updated Green Paper by the end of 2003. Within such a document, the political, economic and legal implications of a European-level regulatory framework, or other regulatory options, such as a directive, would be outlined to ensure openness and competition (European Union, 2002b).

However, the inconclusive results of the EU's legislative proposals concerning media concentration in the mid- to late 1990s would suggest that it will be difficult to achieve consensus among the constituent 
stakeholders including the Commission's directorates, the Parliament, the member states and the media companies themselves. This has led to a number of commentators predicting that the EU will continue to be 'powerless to regulate [on] the issue of concentration, apart from scrutinising [media] mergers and acquisitions' (Papathanassopoulos, 2002: 115). They suggest that the most effective mechanism for the EU to regulate media concentration will ironically continue to be that most apparently liberalizing of single market principles - competition policy.

\section{Competition policy in the audiovisual sector}

The EU Competition Directorate has become an active player in intervening over the European television markets. To preserve competition within the audiovisual sector, the Directorate applies the EC Treaty's competition rulings to make decisions with regard to: mergers, state aid, public enterprises and the liberalization of the market, restrictive agreements and concerted practices, and the abuse of dominant positions (Wheeler, 2001: 3). In respect to European television, the Competition Directorate has been responsible in establishing rules concerning:

- The definition of state aid with regard to PSBs;

- The sale of sport rights to broadcasters; and

- Mergers to stem cross-media and communication concentration (Wheeler, 2001: 4).

\section{State aid with regard to national public service broadcasters}

The Commission has sought to prevent the implementation of anticompetitive agreements and the abuse of dominant market positions by public monopoly operators or service providers. On 15 November 2001, the Directorate published its 'Communication on the Application of State Aid Rules to Public Service Broadcasting' in which it clarified the EU approach on the application of state aid rules to PSBs (European Union, 2001). These were that:

- Member states are free to define the extent of the public service and the way it is financed and organized, according to their preferences, history and needs;

- The Commission called for transparency on these aspects to assess the proportionality of state funding and to control possible abusive practices; 
- Member states will be asked whenever such transparency is lacking to establish a precise definition of the public service remit, to formally entrust it to one or more operators through an official act and to have an appropriate authority monitor its fulfilment; and

- The Commission will only intervene in cases where there is a distortion of competition arising from the aid which cannot be justified with the need to perform the public service as defined by the member state and to provide for its funding (Wheeler, 2001: 6).

Therefore, while member states are regarded as competent for the definition and choice of funding of the public service, the Commission retains a duty to check for abusive practices and any absence of overcompensation on a case-by-case basis. This is in accordance with the 1997 Amsterdam Protocol, which provided the definitions for the appropriate levels of public subsidies so that market distortion should not occur and the Commission's consensus view taken against the introduction of any state aid guidelines in relation to PSBs. In particular, the state aid mechanism has come into effect when the private broadcasters claim that their public rivals have enjoyed a competitive advantage in receiving both public subsidies and advertising revenues. The commercial organizations maintain that this has meant that PSBs have a greater capacity to invest in programming and services, and argue that public financing must be more transparent and proportional to the public service remit.

In this respect, in February 1999, the Commission opened formal state aid procedures regarding PSBs within Italy, France and Spain (who receive revenues from both state subsidy and advertising) and found that their collection of advertising revenues did not unfairly distort the national markets. The launch of new digital services by PSBs has also led to complaints by private rivals. In 1998, the Directorate ruled in favour of two German thematic channels, Kinderkanal and Phoenix, run by the ARD and ZDF public operations (Aid no: NN70/98) (European Union, $1999 \mathrm{~b}$ ) and supported Portuguese public broadcaster Radio Televisão Portuguesa (RTP) when it was challenged by the private company Sociedade Independente de Communicação (Davis, 1998: 94). Further, on 29 September 1999, the European Commission rejected a complaint from BSkyB that the licence funding of the supply of BBC News 24 to cable television viewers was an abuse of European laws on state aids (European Union, 1999c). Thus, although, the Competition Directorate has been innately hostile to PSBs, in the majority of cases concerning state aids 
it has found in favour of them as there has been no clear evidence of market distortion despite the claims of commercial operators. However, as Levy has commented, state aids remain the area where there is perhaps the greatest potential for conflict between the policies adopted by national governments and the way in which [the Competition Directorate] might interpret the competition provisions of the EC treaties' (Levy, 1999: 97).

\section{The sale of sports' rights to broadcasters}

The Competition Directorate has stated that there should be no unjustified restrictions for competition in the sale of rights by sports bodies to broadcasting companies. There are, however, two particular issues related to the marketing of broadcasting rights of sports events: the collective selling and purchasing of broadcasting rights and the exclusivity granted in respect of those rights.

There are significant complexities for broadcasters, sports bodies and competition regulators when a group of football clubs sell rights to matches to the media collectively to extract more revenue. When rights are sold on a collective basis, there is a consequent reduction of the availability of rights in the broadcasting market. The restrictive effects of collective selling agreements undermine the levels of competition among broadcasters and consumer choice. In effect, they amount to price fixing, as they restrict the availability of rights for sports events and strengthen the market position of the dominant broadcasters.

In the Spanish national market, the Directorate forced Telecom giants Telefónica and Sogecable to modify their 'audiovisual sport' agreement when they attempted to fix the price of football matches through a common exploitation of football rights in 2000. In December 2002, the Directorate announced it would consider whether Britain's Football Association Premier League's (FAPL) joint selling of matches to British and Irish television companies should continue on an exclusive basis. In practice, this has meant that only 25 percent of the Premier League matches are broadcast live and only the major media groups (BSkyB) can afford the acquisition and exploitation of such a bundle of rights. This, the Commission believes, has led to high prices and has unfairly blocked other competitors from acquiring key content.

On a pan-European scale, the Directorate also investigated the European Football Union's (UEFA) collective selling of Champions League rights to determine whether this contravened the competition criteria. It announced on 3 June 2002, that UEFA's collective sale had 
distorted competition between broadcasters, encouraged media concentration and barred access to key content for the development of Internet and mobile telephony based sport services. This, the Directorate felt, had contravened the interests of both fans and consumers alike. Therefore, it supported UEFA's new rules which were designed to bring the Champions League's media rights within the reach of Internet content providers, as well as a greater number of television and radio companies. This meant that, rather than UEFA selling the rights as a bundle to only one broadcaster per nation, it will sell several packages of rights for shorter periods of time. Moreover, the football clubs themselves will also be able to exploit some of these rights by directly targeting their fan base (European Union, 2002a).

\section{Mergers}

However, the Competition Directorate's most conspicuous interventions within the audiovisual sector have arisen when it has been called upon to assess new competitive ventures including alliances and mergers, under its merger control rules (Humphreys, 1996: 212). The restructuring of media markets in Europe led to the creation of large media conglomerates of a 'European dimension', whose size (assets of $\boldsymbol{\epsilon} 5$ billion or over worldwide) provided the trigger for EC merger control (Ungerer, 2002: 8). Similarly, competition regulations have been invoked when defensive alliances have occurred in which two or more companies with strong positions in their domestic markets combine to strengthen their positions within the convergent markets (van Miert, 1999: 117).

The Directorate has sought to employ its merger regulations so that it can investigate any proposed cross-communications alliance or merger before its goes ahead rather than having to consider it retrospectively. In interpreting these complex rules, it has realized that rapid technological change may increase forms of market concentration, rather than reduce them. Thus, the competition 'watchdogs' have become concerned with the danger that too much content may be held in the hands of an individual 'gate-keeper' and that consumer choice will be undermined (van Miert, 1997).

\section{Merger cases}

The Competition Directorate has conducted several investigations at national, pan-European and international level to provide rulings concerning the merging or formation of alliances between media, telecommunications and multimedia corporations. At a national level, it 
intervened in the German pay-TV market between 1994 and 1998 to prohibit the two leading German commercial television owners, Bertelsmann and the Kirch group, attempting to develop a joint venture with the German telecommunications monopoly Deutsche Telekom (DT) to be called Media Services Gesellschaft (MSG). The companies intended that the MSG conglomerate should deliver pay-TV channels and interactive services such as video-on-demand through conditional access and decoder systems. In both cases, the Directorate found against MSG due to concerns of market dominance in programme rights, the supply of programming in pay-TV channels and anti-competitive controls over the distribution of set-top boxes (Levy, 1999: 88-9).

At a pan-European level, the Directorate has largely approved the mergers and alliances that have been sought by European media companies. Thus, it supported the authorizations of the French Télévision par Satellite; Bertelsmann/RTL; Canal Plus's acquisition of Nethold and several joint ventures including Canal Plus/Lagardere/Liberty Media; Kirch/BSkyB; and RTL/Canal Plus (Monti, 2001). At an international level, with regard to the mergers between AOL and Time Warner and Vivendi and Universal, the Directorate moved actively to establish specific rulings which allowed the mergers to go ahead within the remit of competition.

In November 2002, the Commission started a detailed investigation into the planned acquisition of Italian pay-TV company Telepiù by Rupert Murdoch's News Corporation. News Corporation intends to merge Telepiù with its own pay-TV operation in Italy, Stream. It has been predicted that within this investigation the Directorate will consider the impact of the merger on the Italian broadcasting market and may determine whether News Corporation really favours the emergence of new competitors or wishes to affect a monopoly (European Union, 2002c). Therefore, according to Competition Commissioner Mario Monti:

A strong, effective competition policy is fundamental to the success of many sectors in Europe, and none more so than the audiovisual sector. A nuanced approach is required, given the complexity and importance of the sector. But that it is nuanced does not mean that it is laissez-faire. (Monti, 2001)

\section{Conclusion}

In establishing its policy instruments for the European television marketplace, the EU has facilitated a regulatory framework which would 
enhance opportunities for expansion within the single market. Most especially, the EU identified the fundamental problem within the European television markets as being one of fragmentation, which it believes has stymied the growth of European television companies when they have tried to compete within the global market. Thus, in attempting to foment the rapid growth of the European television market, the EU has employed the principles of liberalization and harmonization. These goals underpinned the TWF Directive which established liberal rules that aimed to enlarge the European television marketplace and stimulate audiovisual production in member states with a small production capacity.

Simultaneously, the Commission sought to intervene in the Community's broadcasting markets to redress what it has understood as being the undesirable outcomes of an unfettered marketplace. This imperative has created an inherent tension in the EU policy process between dirigistes and liberalizers. Significant divisions emerged in the competing EU directorates who were responsible for the supervision of audiovisual and television services and have most marked with regard to the state aids for PSBs.

This dichotomy has been evident within a number of the other major areas of EU jurisdiction (TWF, media concentration and the regulation of converging services). For instance, the EU declared that it would establish a directive concerning media concentration through the harmonization of national rulings. However, due to the political sensitivity of rulings concerning media ownership, the EU found it impossible to establish a consensus among the responsible directorates, the European Parliament and member states for the directive. These difficulties were exacerbated by the expansion of services and opportunities for new entrants that emerged as a consequence of the digitalization and convergence of communication services. In the event, despite the recent calls from the European Parliament to readdress the Directive on Media Concentration, the EC has preferred to leave the decisions concerning concentration to the auspices of its Competition Directorate.

As consequence, the EU Competition Directorate has become an active player in intervening over the European television market as the centralizing tendencies of media conglomeration have grown. The Directorate has conducted several notifications concerning the merging or formation of joint alliances between media, telecommunications and multimedia corporations. For some, competition policy is an appropriate mechanism through which the EU can meet the conflicting imperatives 
of competitive gain with the demands for the maintenance of plurality and diversity. However, as Jonathan Hardy has commented:

In assessing market power through economic considerations, competition law is unable to grasp more complex operations of cultural or symbolic power which the regulation of media (and now multi-media) pluralism has traditionally sought to address. (Hardy, 2001: 15)

As the converging communication markets take on different characteristics, the democratic flow of information to the public has become a chief concern. To this end, it would appear that competition policy provides only a qualified degree of protection for information markets conceived of as a public good. This is an issue of vital concern, since communication must be considered as having a significant social worth as well as being understood as an economic commodity. These concerns return attention back to the dichotomy between the Commission's interventionists and liberalizers, and suggest that it has been the latter who have largely won the day, despite significant qualifications, in establishing EU rulings for the television and the audiovisual sectors.

Finally, while supranational regulation has grown in terms of its importance in the single European broadcasting market, its impact has been limited on national television industries due to the basic Treaty principles governing subsidiarity. These allow member states a wide degree of autonomy in regulating their own television and communications markets. However, as Europe's influence grows, it must be expected that the EU will seek to rectify its liberalizing tendencies with the needs for a democratic media. The EU then will have to ensure that coherent policies emerge that not only reflect the interests of the Europe's television industries but of its citizens as well.

\section{Bibliography}

Chapman, Peter (2000) 'Monti Grabs Lead Role in the EU Media Show', European Voice 6-12 July.

Collins, Richard (1994) Broadcasting and Audio-Visual Policy in the European Single Market. London: John Libbey.

Collins, Richard (1999) 'European Union Media and Communication Policies', pp. 158-69 in Jane Stokes and Anna Reading (eds) The Media in Britain: Current Debates and Developments. Basingstoke: Palgrave.

Davis, William (1998) The European Television Industry in the 21st Century, Financial Times Specialist Report: Media and Telecoms. London: FT Business Ltd. 
European Union (1989) Council Directive 89/552/EEC of 3 October 1989 on the Coordination of Certain Provisions Laid Down by Law, Regulation or Administrative Action in Member States Concerning the Pursuit of Television Broadcasting Activities. Brussels: European Council.

European Union (1992a) Treaty on European Union (92/C 191/01), signed at Maastricht, 7 February.

European Union (1992b) Pluralism and Media Concentration in the Internal Market: An Assessment of the Need for Community Action (Com (92) 480 Final), 23 December. Brussels: European Commission.

European Union (1994) Communication to Parliament and Council: Follow-up Consultation Process Relating to the Green Paper on 'Pluralism and Media Concentration in the Internal Market: An Assessment of the Need for Community Action' (Com (94) 353 Final), 5 October. Brussels: European Commission.

European Union (1995) Europe and the Global Information Society; Recommendations to the EC (The Bangemann Report), 25 May. Brussels: European Commission.

European Union (1997a) Treaty of Amsterdam amending Treaty on European Union Establishing the European Communities and Certain Related Acts, signed at Amsterdam, 2 October.

European Union (1997b) Protocol on the System of Public Broadcasting in the Member States, Protocols to the Treaty of Amsterdam amending the Treaty on European Union, signed at Amsterdam, 2 October.

European Union (1997c) Convergence of the Telecommunications, Media and Information Technology, and the Implications for Regulations (Com (97) 623). Brussels: European Commission.

European Union (1997d) Directive 97/36/EC amending the 1989 'Television without Frontiers' Directive, OJ L 202, 30 July. Brussels: European Commission.

European Union (1998) The Digital Age: European Audiovisual Policy, Report by the High Level Group on Audiovisual Policy chaired by Commissioner Marcelino Oreja, October. Brussels: European Commission.

European Union (1999a) Communication to the European Parliament, the Council, the Economic and Social Committee and the Committee to the Regions: The Convergence of Telecommunications, Media and Information Technology Sectors, and the Implications for Regulation: Results of the Public Consultation on the Green Paper (Com (97) 623). Brussels: European Commission.

European Union (1999b) Commission Decision on State Aid Financing of Kinderkanal and Phoenix Specialist Channels. Brussels: European Commission.

European Union (1999c) Commission Decision on State Aid Financing of a 24 Hour News Channel out of a Licence Fee by the BBC, SG(99) D/10201, 29 September. Brussels: European Commission.

European Union (1999d) Principles and Guidelines for the Community's Audiovisual Policy in the Digital Age (Com 657 Final), 14 December. Brussels: European Commission. 
European Union (2001) Communication from the Commission on the Application of State Aid Rules to Public Service Broadcasters, 15 November. Brussels: European Commission.

European Union (2002a) Press Release: 'Commission Welcomes UEFA's New Policy for Selling the Media Rights to the Champions League', 3 June. Brussels: European Commission.

European Union (2002b) European Parliament Calls for a Resolution on Media Concentration, 20 November. Brussels: European Parliament.

European Union (2002c) Press Release: 'Commission Opens In-Depth Probe into the Acquisition of Telepiù by Newscorp', 29 November. Brussels: European Commission.

European Union (2003) Fourth Report to the Council of Europe and the European Parliament on the Application of the TWF Directive, 6 January. Brussels: European Commission.

Hardy, Jonathan (2001) 'Border Crossings; Convergence, Cross-Media Promotion and Commercial Speech in UK Communications Policy', paper presented at the 51st Political Studies Association Conference, University of Manchester.

Harcourt, Alison (2002) 'Review of David A.L. Levy Europe's Digital Revolution', Convergence: The Journal of Research in to New Media Technologies: Special Issue on Telecommunication Regulation in Europe 8(2): 116-17.

Harcourt, Alison and Claudio M. Radaelli (1997) 'Limits to Technocratic Regulation and the European Union - The Case of Media Ownership Regulation', paper for 47th Political Studies Association Conference, University of Ulster.

Humphreys, Peter J. (1996), Mass Media and Media Policy in Western Europe. Manchester: Manchester University Press.

Iosifidis, Petros (1997) 'Pluralism and Media Concentration Policy in the European Union', The Public 4(1): 85-104.

Jones, Tim (2000) ' (93)New Economy(94) Mega Media Marriage Prompts AgeOld Competition Worries', European Voice 19-25 October.

Levy, David A.L. (1999), Europe's Digital Revolution: Broadcasting Regulation, the $E U$ and the Nation State. London: Routledge.

Monti, Mario (2002) 'Does EC Competition Policy Help or Hinder the European Audiovisual Industry?', 26 November. London: British Screen Advisory Council (BSAC).

Negrine, Ralph and Styliannos Papathanassopoulos (1990) The Internationalisation of Television. London: Pinter.

Papathanassopoulos, Styliannos (2002) European Television in the Digital Age. Oxford: Polity.

Radaelli, Claudio M. (1999) Technocracy and the European Union. London: Longman.

Reding, Vivianne (2000) Member of the European Commission responsible for Education and Culture, 'Community Audiovisual Policy in the 21st 
Century Content Without Frontiers?, 30 November. London: British Screen Advisory Council (BSAC); at: www.europa.eu.int/comm/index_en.htm10 (accessed 7 November 2003).

Ungerer, Herbert (2002) 'Media in Europe: Media and EU Competition Law', paper presented at Conference on Media in Poland by the Poland Confederation of Private Employers, Warsaw, 13 February.

Van Miert, Karel (1997) 'A European View on Opening Up Networked Industries to Competition: The Telecommunications Example', VIIIth International Antitrust Conference, 27 October.

Van Miert, Karel (1999) 'Competition Rules OK', pp. 113-19 in Anne Leer (ed.) Masters of the Wired World: Cyberspace Speaks Out. London: Financial Times/ Pitman.

Wheeler, Mark (2001) EU Competition Issues in the Telecommunications and Audiovisual Industries, November. London: British Screen Advisory Council (BSAC). 